\title{
Clinical anatomy and clinical significance of the cervical intervertebral foramen: a review
}

\author{
G. Sioutas, S. Kapetanakis \\ Department of Anatomy, Medical School of Alexandroupolis, Democritus University of Thrace, Greece
}

[Received: 1 June 2015; Accepted: 13 July 2015]

The aim of this paper is to summarise the knowledge about the anatomy of the cervical intervertebral foramen as a whole. Such reviews are rare in the literature. The intervertebral or neural foramen is the opening between the spinal canal and the extraspinal region. It is located between the vertebral pedicles at all spinal levels. A number of structures pass through the foramen: nerves, vessels and ligaments. We describe the bony borders and dimensions of the foramen, the adjacent ligaments, the arteries and veins passing through or neighbouring it, and the neural components. Many procedures are performed in the area of the cervical intervertebral foramen. Knowledge of the anatomy of the foramen is essential in order to operate to the area and to minimize iatrogenic injuries. (Folia Morphol 2016; 75, 2: 143-148)

Key words: intervertebral foramen, neural foramen, cervical, anatomy, review

\section{INTRODUCTION}

The intervertebral or neural foramen is the opening between the spinal canal and the extraspinal region. It lies between the vertebral pedicles at all spinal levels $[8,10,16]$. Many studies have evaluated the vertebral body, spinal canal, and spinal cord [15, 26, 35]. However, an extremely limited number of studies have reviewed the complete anatomy of the cervical intervertebral foramen (Table 1) [8, 10, 25, 38, 40, 48]. In fact, there is only one review article describing the anatomy of cervical intervertebral foramen as a whole, which focused on vascularisation. The following review is a thorough anatomic description of the intervertebral foramen, with its contents, from C2 to T1 level.

\section{THE BONY BORDERS OF THE INTERVERTEBRAL FORAMEN}

The borders of the intervertebral foramen (Fig. 1) are inferiorly and superiorly the neighbouring pedi- cles, posteriorly the medial aspect of the facet joint and the adjacent part of the articular column, and anteriorly the posterolateral aspect of the uncovertebral joint, the intervertebral disc, and the inferior part of the suprajacent vertebrae. The nerve root must cross three successive areas to go from the intradural to the extravertebral region $[40,48,50]$. Thus, the intervertebral foramen is divided into three anatomic regions: 1. A medial area: It is located within the medial orifice of the intervertebral foramen. 2. A narrow intermediate area: Actually, it constitutes the intervertebral foramen. 3. A lateral area: The spinal nerve rests in the groove of the transverse process [10].

These three areas create a canal of $20 \mathrm{~mm}$ in length. The intervertebral foramen is located anteriorly to the vertebral canal at an angle of $45^{\circ}$ relative to the coronal plane $[10,19]$. In other words, the intervertebral foramen is located anteriorly to the vertebral canal at an angle of $45^{\circ}$ relative to the coronal plane [19]. Therefore, the oblique or axial views have

Address for correspondence: Dr S. Kapetanakis, Orthopaedic Surgeon, Lecturer of Anatomy, Department of Anatomy, Medical School, Democritus University of Thrace, Dragana Medical School of Alexandroupolis, Alexandroupolis 68100, Greece, tel: +306972707384, fax: +302551030537, e-mail: stkapetanakis@yahoo.gr 
Table 1. Articles where the anatomy of cervical intervertebral foramen is described as a whole. Quantitative dimensional studies are not included

\begin{tabular}{|c|c|c|c|c|c|c|}
\hline Article type & Study aim & Material & Date & Authors & Journal & Reference \\
\hline Review & $\begin{array}{c}\text { Anatomy of the foramina } \\
\text { in the cervical and lumbar } \\
\text { spines and of spinal cord } \\
\text { vascularisation }\end{array}$ & Cadaveric, MRI & 2012 & Demondion et al. & $\begin{array}{l}\text { Diagnostic and } \\
\text { Interventional } \\
\text { Imaging }\end{array}$ & [10] \\
\hline Anatomic study & $\begin{array}{l}\text { Correlative anatomic and } \\
\text { MRI study of cervical } \\
\text { neural foramina }\end{array}$ & $\begin{array}{l}\text { MRI in cadavers } \\
\text { and healthy vol- } \\
\text { unteers, cadaver } \\
\text { cryomicrotome } \\
\text { sections }\end{array}$ & 1988 & Czervionke et al. & Radiology & [8] \\
\hline Anatomic study & $\begin{array}{l}\text { The anatomic relations of } \\
\text { the foramina, nerve roots, } \\
\text { and intradural rootlets }\end{array}$ & $\begin{array}{l}18 \text { cadavers, } \\
\text { surgical } \\
\text { microscope }\end{array}$ & 2000 & Tanaka et al. & Spine & [48] \\
\hline Surgical technique article & $\begin{array}{l}\text { Short description of } \\
\text { normal and pathological } \\
\text { foraminal anatomy. } \\
\text { Description of surgical } \\
\text { technique }\end{array}$ & CT, drawing & 2004 & Russell et al. & Neurosurgery & [40] \\
\hline Imaging anatomic study & $\begin{array}{l}\text { Correlation of microtomy } \\
\text { and CT anatomy }\end{array}$ & $\begin{array}{l}\text { CT of } 19 \text { cervical } \\
\text { spine specimens }\end{array}$ & 1985 & Pech et al. & Radiology & [38] \\
\hline Imaging anatomic study & $\begin{array}{l}\text { Normal spinal anatomy } \\
\text { as defined by MRI. } \\
\text { A short description of } \\
\text { normal anatomy of the } \\
\text { cervical neural foramina }\end{array}$ & MRI & 2011 & $\begin{array}{c}\text { Jindal } \\
\text { and Pukenas }\end{array}$ & $\begin{array}{l}\text { Magnetic Reso- } \\
\text { nance Imaging } \\
\text { Clinics of North } \\
\text { America }\end{array}$ & [25] \\
\hline
\end{tabular}

CT — computed tomography; MRI — magnetic resonance imaging

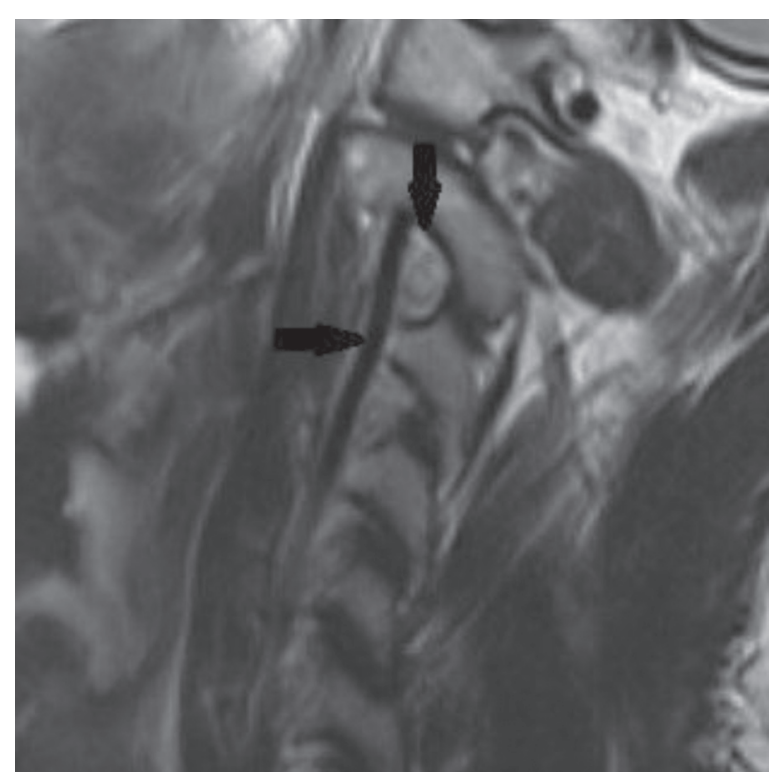

Figure 1. Magnetic resonance imaging of the cervical spine, sagittal T2-weighted image. Arrow pointing down: cervical intervertebral foramen. Arrow pointing right: vertebral artery.

greater confidence rates than the sagittal views, in order to evaluate the presence of foraminal stenosis or of a disc herniation [17, 25, 36, 37, 44].
Other researchers divide the intervertebral foramen into two anatomic zones: the entrance zone (medial half of the intervertebral foramen) and the exit zone (lateral half of the intervertebral foramen) [48]. The cervical nerve groove is also divided into three zones: a medial zone (pedicle), a middle zone (vertebral artery foramen), and a lateral zone [11]. The first intervertebral space is not a real foramen, because there is not any bone structure posteriorly $[5,31]$.

\section{Dimensions of the intervertebral foramen}

The intervertebral foramen is ovoid in shape [29]. The normal foramen height is $11.08 \pm 1.88 \mathrm{~mm}$, width $5.69 \pm 1.91 \mathrm{~mm}$, and foramen area $5.61 \pm$ $\pm 1.83 \mathrm{~mm}^{2}$ [45]. The largest foraminal area is at level C2-C3, and the smallest at C7-T1. The width of the foramina is approximately one half its height [29]. The minimum width of the medial zone of the nerve groove is 1-2 $\mathrm{mm}$ for all levels [11].

Cervical intervertebral foramina are larger in healthy than in symptomatic people. Foraminal height changes with age and width decreases with age [23]. Foraminal height and width increase from the upper to the lower intervertebral foramina, except at C2-C3. 
Females show larger values for intervertebral foramen width than males [11].

\section{Dimensions and movement}

Understanding the effects of cervical position on intervertebral foraminal size is important in the assessment of pathology and injury [53]. Flexion increases the foraminal height width and foraminal area. Extension decreases them $[27,33,41]$. After cervical retraction, dimensions of the cervical neural foramina show no significant change, except at C3-C4 [29]. Cervical traction causes widening of the cervical neural foramina and reduction of the intradiscal pressure [42]. The foraminal area and height are increased [30].

\section{THE LIGAMENTS OF THE INTERVERTEBRAL FORAMEN}

The radicular nerves are covered by the radicular sheath. The radicular sheath continues as the perineural investment of the radicular nerve. It blends with the periradicular fibrous tissue from the posterior longitudinal ligament. More laterally, it continues as the fibrous investment of the vertebral artery [48].

\section{The ligamentum flavum}

The lateral border of the spinal canal is covered posteriorly by the lateral aspects of a superior and inferior lamina. Anterior to the lamina, the ligamentum flavum is attached to two-thirds of the inferior-surface of the superior lamina, but inferiorly it is attached only to the superior border of the inferior lamina. More lateral, the ligamentum flavum ends $1-2 \mathrm{~mm}$ before the medial border of the neural foramen [40].

\section{Extraforaminal ligaments}

\section{of the cervical spinal nerves}

Direct ligamentous structures exist between extraforaminal cervical spinal nerves and nearby structures. They are divided into radiating ligaments and transforaminal ligaments [43].

Radiating ligaments consist of a ventral and dorsal part. The ventral and dorsal extraforaminal ligaments also consist of a superior and inferior part. The inferior ventral and dorsal ligaments are attached to each other [28, 43].

Transforaminal ligaments $[2,7]$ can be found in the cervical spine [1]. They originate from the antero-inferior margin of the superior transverse process and insert into the superior margin of the anterior tubercle of the inferior transverse process. They orientate to the longitudinal direction of the spinal nerves and cross them ventrally. The posterior side of the transforaminal ligaments is strongly adherent to the spinal nerve sheath. Usually, an intervertebral foramen contains no more than one transforaminal ligament [43].

\section{The posterior longitudinal ligament and} the perivascular fibroligamentous tissue

The uncinate process and its covering ligaments are barriers that prevent the nerve root and the vertebral artery against damage [51]. The posterior longitudinal ligament lies posteriorly of the vertebral bodies and has two loosely connected layers named the anterior layer and the posterior layer $[6,20]$. It is recognised by surgeons to protect the neural and vascular structures.

The posterior longitudinal ligament also separates into two fibroligamentous parts at the posterior corner of the uncinate process. It is called the perivascular fibroligamentous tissue. It covers the lateral aspect of the uncinate process and the vascular content of the transverse foramen. A venous plexus lies between the two layers of the posterior longitudinal ligament, at the transition from posterior longitudinal ligament to the perivascular fibroligamentous tissue $[21,51,52]$.

\section{ARTERIAL VERTEBRAL SYSTEM}

The radiculomedullary arteries

The radicular artery divides into an anterior and a posterior radicular artery. The radicular arteries course along the anterior side of the accompanying roots. Only one artery out of eight to ten reaches the spinal cord [10]. From the intervertebral foramina aspect, five radicular arteries $(C 5, C 6$, two at $C 7, C 8)$ enter the foramina, either anteriorly or posteriorly, to supply the anterior and posterior spinal arteries [22].

\section{Vertebral, ascending cervical and deep cervical artery}

The vertebral artery (Fig. 1) is the parent vessel for several segmental medullary vessels, which branch from the medial surface of the vessel $[4,18,19,24$, 47]. If the ascending cervical artery supplies a spinal branch, it occurs at the C3-C4 or C4-C5 foramen, and the spinal branch enters the posterior-inferior aspect of the external intervertebral foraminal opening [24]. The deep cervical artery often gives branches to the roots of the brachial plexus or muscles. In some instances, the vessel forms spinal branches and enters 
the posterior aspect of the intervertebral foramen, directly posterior to the exiting ventral ramus. These cervical spinal branches always enter at $\mathrm{C} 5-\mathrm{C} 6, \mathrm{C} 6-\mathrm{C} 7$ or C7-T1 level [24].

\section{THE VEINS}

The upper half of the intervertebral foramen contains fat and small veins $[9,48]$. The abundant epidural veins in the cervical region, communicate with the venous plexuses located around the vertebral artery [10]. Blood is drained by vessels that flows into the perimedullary veins. There are two pathways at these veins [38]. The epidural venous plexuses are in communication with the extravertebral system through the intervertebral foraminal veins, by two veins $[6,10,12]$. The spinal roots are covered by veins, which have a horizontal course to the vertebral vein. The anterior spinal vein is located at the median fissure along the spinal artery and is large at the cervical level [6].

\section{THE NERVES}

\section{The nerve roots}

The shape of the intervertebral foramina approximates a funnel [48]. As the nerve roots pass through the intervertebral foramen they are found in the lower third of the foramen $[10,19]$.

The cervical nerves result from the junction of an anterior and a posterior root (Fig. 2). The anterior (motor) root is thin, and consists of four to seven rootlets from the anterior collateral sulcus of the spinal cord. It has close connections with the vertebral uncus anteriorly and with the pedicle of the vertebra inferiorly. The posterior (sensory) root, is three times larger than the anterior root, and is composed of four to ten rootlets that penetrate the posterior collateral sulcus. It is located posteriorly and superiorly to the anterior root [38]. The cervical nerve roots extend anterolaterally at a $45^{\circ}$ angle to the coronal plane and inferiorly at about $10^{\circ}$ to the axial plane [9]. The radicular nerve occupies one fourth to one third of the intervertebral foramen diameter [48]. The dorsal and ventral roots of the $\mathrm{C} 3-\mathrm{C} 7$ nerves are situated in a groove described above $[11,48]$.

Each of the C5-C8 ventral root contains 14 to 23 bundles of rootlets, and each dorsal root consists of eight to 12 bundles rootlets. The ventral and dorsal rootlets disconnect from the spinal cord approximately one disc level higher than the corresponding intervertebral foramen [48].

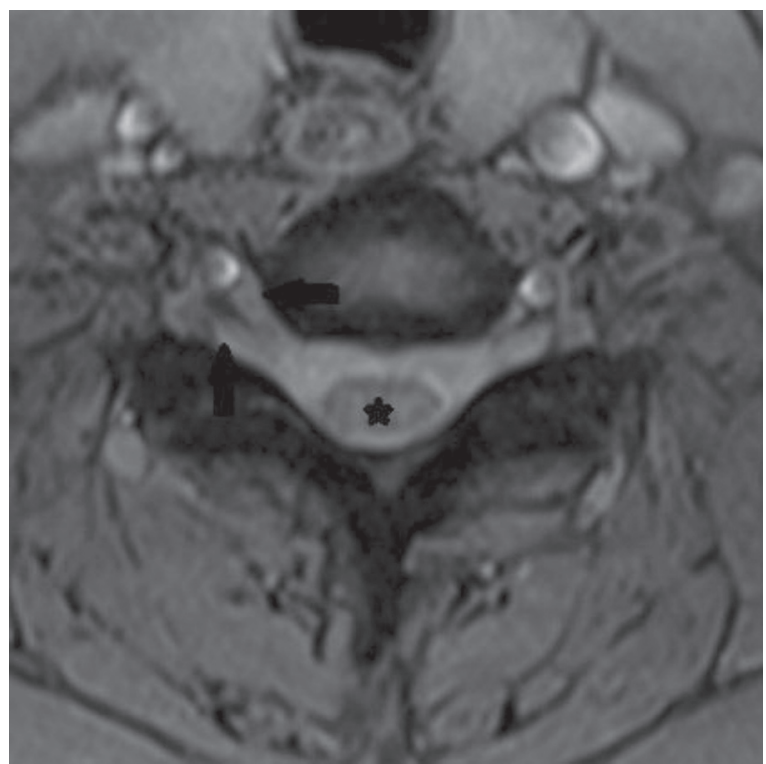

Figure 2. Magnetic resonance imaging of the cervical spine, axial T2-weighted image. Arrow pointing left: anterior nerve root. Arrow pointing up: posterior nerve root and ganglion. Star: spinal cord.

\section{Nerve and meningeal relations}

The neural structures and their surrounding connective tissue fill $35 \%$ to $50 \%$ of the cross-sectional area of the intervertebral foramen. Only the fourth, fifth, and sixth cervical spinal nerves have a strong attachment to the vertebral column, and this is to the gutter of the vertebral transverse process $[13,46,49]$.

Each pair of ventral and dorsal nerve roots invaginate the arachnoid and the dura to form a funnel-shaped depression in the wall of the dural sac. Some nerve roots first descend intradurally to up to $8 \mathrm{~mm}$ below the centre of the foramen. At this level, they perforate the arachnoid and dura [13, 14, 32]. The nerve roots are angulated at the site at which they pass through the dura [49].

\section{The dorsal root ganglion}

The spinal ganglion is a spindle-shaped swelling that each posterior root carries, and contains the cell bodies of the sensory neurons. It lies outside the neural foramen between the vertebral artery and a small concavity in the superior articular process $[5,9,10,31,39,49]$.

\section{CONCLUSIONS}

Many procedures are performed in the area of the cervical intervertebral foramen. Cervical foraminotomy and placing lateral mass screws are performed 
for frequently. However, anatomic reviews have not described the anatomy of the foramen thoroughly $[3,11,48]$. Knowledge of the anatomy of the foramen is also essential to all radiologists performing interventional procedures in order to avoid iatrogenic risks. The cervical intervertebral foramina are the most frequent sites of injections performed by radiologists $[10,21,24]$. Dimensions of intervertebral foramina are clinically important in the diagnosis of foraminal stenosis and radiculopathy [11, 34].

In conclusion, surgeons have to fully understand the three-dimensional anatomy of the cervical intervertebral foramen in order to conduct an optimal surgical procedure [40].

\section{REFERENCES}

1. Bakkum B, Berthiaume R (1994) Transforaminal ligaments of the human cervical spine. In: Proceedings of the Eleventh Annual Meeting of the American Association of Clinical Anatomists. American Association of Clinical Anatomists, Galveston, p. 22.

2. Bakkum BW, Mestan M (1994) The effects of transforaminal ligaments on the sizes of T11 to L5 human intervertebral foramina. J Manipulative Physiol Ther, 17: 517-522.

3. Barakat M, Hussein $Y$ (2012) Anatomical study of the cervical nerve roots for posterior foraminotomy: cadaveric study. Eur Spine J, 21: 1383-1388.

4. Beckworth WJ, Sood R, Katzer AF, Wu B (2013) Anomalous location of the vertebral artery in relation to the neural foramen. Implications for cervical transforaminal epidural steroid injections. Pain Med, 14: 1119-1125.

5. Bilge $O$ (2004) An anatomic and morphometric study of $\mathrm{C} 2$ nerve root ganglion and its corresponding foramen. Spine (Phila Pa 1976), 29: 495-499.

6. Chaynes P, Verdié JC, Moscovici J, Zadeh J, Vaysse P, Becue J (1998) Microsurgical anatomy of the internal vertebral venous plexuses. Surg Radiol Anat, 20: 47-51.

7. Cramer GD, Skogsbergh DR, Bakkum BW, Winterstein JF, Yu S, Tuck NR Jr (2002) Evaluation of transforaminal ligaments by magnetic resonance imaging. J Manipulative Physiol Ther, 25: 199-208.

8. Czervionke LF, Daniels DL, Ho PS, Yu SW, Pech P, Strandt J, Williams AL, Haughton VM (1988) Cervical neural foramina: correlative anatomic and MR imaging study. Radiology, 169: 753-759.

9. Daniels DL, Hyde JS, Kneeland JB, Jesmanowicz A, Froncisz W, Grist TM, Pech P, Williams AL, Haughton VM (1986) The cervical nerves and foramina: local-coil MR imaging. Am J Neuroradiol, 7: 129-133.

10. Demondion X, Lefebvre G, Fisch O, Vandenbussche L, Cepparo J, Balbi V (2012) Radiographic anatomy of the intervertebral cervical and lumbar foramina (vessels and variants). Diagn Interv Imaging, 93: 690-697.

11. Ebraheim NA, An HS, Xu R, Ahmad M, Yeasting RA (1996) The quantitative anatomy of the cervical nerve root groove and the intervertebral foramen. Spine (Phila Pa 1976), 21: 1619-1623.

12. Flannigan BD, Lufkin RB, McGlade C, Winter J, Batzdorf $U$, Wilson G, Rauschning W, Bradley WG Jr (1987) MR imaging of the cervical spine: neurovascular anatomy. Am J Roentgenol, 148: 785-790.

13. Frykholm R (1951) Lower cervical nerve roots and their investments. Acta Chir Scand, 101: 457-471.

14. Frykholm R (1951) The mechanism of cervical radicular lesions resulting from friction or forceful traction. Acta Chir Scand, 102: 93-98.

15. Gilad I, Nissan M (1986) A study of vertebra and disc geometric relations of the human cervical and lumbar spine. Spine (Phila Pa 1976), 11: 154-157.

16. Gilchrist RV, Slipman CW, Bhagia SM (2002) Anatomy of the intervertebral foramen. Pain Physician, 5: 372-378.

17. Goodman BS, Geffen JF, Mallempati S, Noble BR (2006) MRI images at a 45-degree angle through the cervical neural foramina: a technique for improved visualization. Pain Physician, 9: 327-332.

18. Hage ZA, Amin-Hanjani S, Wen D, Charbel FT (2012) Surgical management of cervical radiculopathy caused by redundant vertebral artery loop. J Neurosurg Spine, 17: 337-341.

19. Hartman J (2014) Anatomy and clinical significance of the uncinate process and uncovertebral joint: A comprehensive review. Clin Anat, 27: 431-440.

20. Hayashi K, Yabuki T, Kurokawa T, Seki H, Hogaki M, Minoura S (1977) The anterior and the posterior longitudinal ligaments of the lower cervical spine. J Anat, 124: 633-636.

21. Hernández-García JM, Reina MA, Prats-Galino A, De Andrés JA (2011) Morphologic study of nerve root and types of needle used in transforaminal injections. Reg Anesth Pain Med, 36: 278-281.

22. Hoeft MA, Rathmell JP, Monsey RD, Fonda BJ (2006) Cervical transforaminal injection and the radicular artery: variation in anatomical location within the cervical intervertebral foramina. Reg Anesth Pain Med, 31: 270-274.

23. Humphreys SC, Hodges SD, Patwardhan A, Eck JC, Covington LA, Sartori M (1998) The natural history of the cervical foramen in symptomatic and asymptomatic individuals aged 20-60 years as measured by magnetic resonance imaging. A descriptive approach. Spine (Phila Pa 1976), 23: 2180-2184.

24. Huntoon MA (2005) Anatomy of the cervical intervertebral foramina: vulnerable arteries and ischemic neurologic injuries after transforaminal epidural injections. Pain, 117: 104-11.

25. Jindal G, Pukenas B (2011) Normal spinal anatomy on magnetic resonance imaging. Magn Reson Imaging Clin N Am, 19: 475-488.

26. Kameyama T, Hashizume $Y$, Ando T, Takahashi A, (1994) Morphometry of the normal cadaveric cervical spinal cord. Spine (Phila Pa 1976), 19: 2077-2081.

27. Kitagawa T, Fujiwara A, Kobayashi N, Saiki K, Tamai K, Saotome K (2004) Morphologic changes in the cervical neural foramen due to flexion and extension: in vivo imaging study. Spine (Phila Pa 1976), 29: 2821-2825.

28. Kraan GA, Smit TH, Hoogland PV (2011) Extraforaminal ligaments of the cervical spinal nerves in humans. Spine J, 11: 1128-1134.

29. Lentell G, Kruse M, Chock B, Wilson K, Iwamoto M, Martin R (2002) Dimensions of the cervical neural foramina in resting and retracted positions using magnetic resonance imaging. J Orthop Sports Phys Ther, 32: 380-390. 
30. Liu J, Ebraheim NA, Sanford CG Jr, Patil V, Elsamaloty H, Treuhaft K, Farrell S, (2008) Quantitative changes in the cervical neural foramen resulting from axial traction: in vivo imaging study. Spine J, 8: 619-623.

31. Lu J, Ebraheim NA (1998) Anatomic considerations of C2 nerve root ganglion. Spine (Phila Pa 1976), 23: 649-652.

32. Nathan H, Feuerstein M (1970) Angulated course of spinal nerve roots. J Neurosurg, 32: 349-352.

33. Nuckley DJ, Konodi MA, Raynak GC, Ching RP, Mirza SK (2002) Neural space integrity of the lower cervical spine: effect of normal range of motion. Spine (Phila Pa 1976), 27: 587-595.

34. Oh SH, Perin NI, Cooper PR (1996) Quantitative three-dimensional anatomy of the subaxial cervical spine: implication for anterior spinal surgery. Neurosurgery, 38: 1139-1144.

35. Panjabi MM, Duranceau J, Goel V, Oxland T, Takata K (1991) Cervical human vertebrae. Quantitative three-dimensional anatomy of the middle and lower regions. Spine (Phila Pa 1976), 16: 861-869.

36. Park H-J, Kim SS, Lee S-Y, Park N-H, Chung E-C, Rho M-H, Kwon H-J, Kook S-H (2013) A practical MRI grading system for cervical foraminal stenosis based on oblique sagittal images. Br J Radiol, 86: 201-215.

37. Park MS, Moon SH, Lee HM, Kim TH, Oh JK, Lee SY, Oh JB, Riew KD (2014) Diagnostic value of oblique magnetic resonance images for evaluating cervical foraminal stenosis. Spine J, 15: 607-611.

38. Pech P, Daniels DL, Williams AL, Haughton VM (1985) The cervical neural foramina: correlation of microtomy and CT anatomy. Radiology, 155: 143-146.

39. Rosner MJ, Whaley R (1984) Anomalous exit of the C-6 nerve root via the C-6. C-7 foramen, Neurosurgery, 14: 740-743.

40. Russell SM, Benjamin V (2004) Posterior surgical approach to the cervical neural foramen for intervertebral disc disease. Neurosurgery, 54: 662-665.

41. Sato T, Masui K (2013) Morphologic differences in intervertebral foramina: a radiographic study of cervical spine positions in asymptomatic men. J Manipulative Physiol Ther, 36: 327-332.

42. Savva C, Giakas G (2013) The effect of cervical traction combined with neural mobilization on pain and disability in cervical radiculopathy. A case report. Man Ther, 18: 443-446.

43. Shi $B$, Zheng $X$, Zhang $H$, Sun $C$, Cao $Y$, Jin $A$, Ding $Z$ (2015) The morphology and clinical significance of the extraforaminal ligaments at the cervical level. Spine (Phila Pa 1976), 40: E9-E17.

44. Shim JH, Park CK, Lee JH, Choi JW, Lee DC, Kim DH, Kim JK, Hwang JH (2009) A comparison of angled sagittal MRI and conventional MRI in the diagnosis of herniated disc and stenosis in the cervical foramen. Eur Spine J, 18: 1109-1116.

45. Sohn HM, You JW, Lee JY (2004) The relationship between disc degeneration and morphologic changes in the intervertebral foramen of the cervical spine: a cadaveric MRI and CT study. J Korean Med Sci, 19: 101-106.

46. Sunderland S (1974) Meningeal-neural relations in the intervertebral foramen. J Neurosurg, 40: 756-763.

47. Takahashi M (1974) Anatomy of the vertebrobasilar vascular system. In: Atlas of Vertebral Angiography. University Park Press, Baltimore, pp. 17-58.

48. Tanaka N, Fujimoto Y, An HS, Ikuta Y, Yasuda M (2000) The anatomic relation among the nerve roots, intervertebral foramina, and intervertebral discs of the cervical spine. Spine, 25: 286-291.

49. Terzis JK, Novikov ML (2005) Radiological and electrophysiological detection of nerve roots avulsion in patients with birth-related brachial plexus paralysis. Seminars in Plastic Surgery, 19: 24-41.

50. Tubbs RS, Rompala OJ, Verma K, Mortazavi MM, Benninger B, Loukas M, Chambers MR (2012) Analysis of the uncinate processes of the cervical spine: an anatomical study. J Neurosurg Spine, 16: 402-407.

51. Yilmazlar S, Ikiz I, Kocaeli H, Tekdemir I, Adim SB (2003) Details of fibroligamentous structures in the cervical unco-vertebral region: an obscure corner. Surg Radiol Anat, 25: 50-53.

52. Yilmazlar S, Kocaeli H, Uz A, Tekdemir I (2003) Clinical importance of ligamentous and osseous structures in the cervical uncovertebral foraminal region. Clin Anat, 16: 404-410.

53. Yoo JU, Zou D, Edwards WT, Bayley J, Yuan HA (1992) Effect of cervical spine motion on the neuroforaminal dimensions of human cervical spine. Spine (Phila Pa 1976), 17: 1131-1136. 